\title{
EFEKTIVITAS PELAKSANAAN TUGAS DAN FUNGSI BAGIAN HUMAS \\ DAN PROTOKOL DALAM MENJAGA CITRA KEPALA DAERAH PADA HUMAS DAN PROTOKOL SEKRETARIAT DAERAH KABUPATEN JEMBRANA
}

\author{
I Gede Arya Suta Satya Pramana \\ Ni Wayan Sutiani \\ Fakultas Ilmu Sosial dan Ilmu Politik Universitas Mahendradatta - Denpasar \\ email:
}

\begin{abstract}
Abstrak: Setiap instansi baik pemerintah, perusahaan, ataupun lembaga lainnya pasti mempunyai Humas dan Protokol. Humas dan Protokol mempunyai tugas dan fungsi untuk bertanggung jawab dan mempertahankan citra positif yang telah ada pada suatu instansi atau perusahaan serta mencitrakan lebih baik kembali dimana tempat instansi atau perusahaan itu berada, berperan menyampaikan suatu kebijakan atau semua informasi yang dilaksanakan oleh instansi atau suatu perusahaan. Dari latar belakang di atas, maka tujuan penelitian ini adalah untuk mengetahui Bagaimanakah Efektivitas Pelaksanaan Tugas dan Fungsi Bagian Humas dan Protokol dalam Menjaga Citra Kepala Daerah (Studi Pada Bagian Humas dan Protokol Sekretariat daerah Kabupaten Jembrana.Data dalam penelitian ini adalah data sekunder kualitatif. Populasi diambil dari pegawai pada Bagian Humas dan Protokol Sekretariat daerah Kabupaten Jembrana yang berjumlah 35, metode sampel yang digunakan adalah metode sensus. Teknik analisis data yang digunakan adalah analisis deskriptif kualitatif.Metode pengumpulan data yang digunakan dalam penelitian ini adalah metode wawancara dan studi dokumentasi.Hasil penelitian menunjukkan bahwa Efektivitas pelaksanaan tupoksi bagian Humas dan Protokol dalam menjaga citra kepala daerah pada Setda Kabupaten Jembrana telah berjalan dengan baik yang dilihat dari indikator: Penerimaan tamu/audensi (dalam dan luar negeri) terlaksana sesuai dengan standar yang ditentukan. Kunjungan tamu (dalam dan luar negeri) dilaksanakan sesuai dengan pedoman yang berlaku.Perjalanan ke daerah/luar negeri dilaksankan sesuai dengan pedoman yang ditentukan.Pengaturan rapat sidang yang dilaksanakan dengan baik.Penyelenggaraan resepsi/jamuan makan yang sudah dilaksanakan dengan baik.Penyelenggaraan upacara-upacara kenegaraan sudah sesuai dengan aturan yang ditetapkan. Dengan terlaksananya tugas dan fungsi bagian Humas dan Protokol maka citra kepala daerah dapat terjaga dengan baik, yang dilihat dari indikator: Personality Kepala daerah meningkat dengan terlaksananya kegiatan humas dan protokol dengan baik. Reputation Kabupaten Jembrana meningkat terlaksananya kegiatan humas dan protokol dengan baik. Value atau nilai Kabupaten Jembrana yang meningkat dengan terlaksananya kegiatan-kegiatan dari humas dan prokotol dengan baik.Identity atau jadi diri bisa dilihat degnan terlaksananya kegiatan humas dan protokol dengan baik.
\end{abstract}

Kata kunci : Efektivitas, Tugas dan Fungsi, Bagian Humas dan Protokol, Citra Kepala Daerah

Ni Wayan Sutiani 
Abstract,Every government agency, company, or other institution must have a Public Relations and Protocol. Public Relations and Protocols have the duty and function to take responsibility and maintain a positive image that already exists in an agency or company and to better re-image where the agency or company is located, has the role of delivering a policy or all information carried out by an agency or a company. From the above background, the purpose of this study is to find out how the effectiveness of the implementation of the duties and functions of the Public Relations and Protocol Section in Maintaining the Image of the Regional Head (Study in the Public Relations and Protocol Section of the Jembrana Regency Regional Secretariat.The data in this study are qualitative secondary data. The population was taken from employees in the Public Relations and Protocol Section of the District Secretariat of Jembrana totaling 35 , the sample method used was the census method. The data analysis technique used is descriptive qualitative analysis. Data collection methods used in this research are interview and documentation study methods. The results of the study showed that the effectiveness of the duties and functions of the Public Relations and Protocol section in maintaining the image of regional heads in the Regional Secretariat of Jembrana District had been going well, as seen from the indicators: Reception / hearing (domestic and foreign) was carried out in accordance with the specified standards. Guest visits (domestic and foreign) are carried out in accordance with applicable guidelines. Travel to the region / Overseas is carried out in accordance with specified guidelines. Meeting / session arrangements are well implemented. The holding of a reception / banquet has been carried out well. The implementation of the ceremonies is in accordance with the established rules. With the implementation of the duties and functions of the Public Relations and Protocol section, the image of the regional head can be maintained properly, as seen from the indicators: Personality of the regional head increases with the implementation of public relations and protocol activities properly. Reputation of Jembrana Regency has improved the implementation of public relations and procolo activities. The value of Jembrana Regency increases with the implementation of public relations and procolo activities properly. Identity or self can be seen by the implementation of public relations and protocol activities well.

\section{Keywords: Effectiveness, Duties and Functions, Public Relations and Protocol, Image of Regional Head}

\section{A. Pendahuluan}

Humas pemerintah mempunyai peran penting untuk membuka ruang bagi masyarakat atau publik untuk mendapatkan akses informasi yang dibutuhkan.Informasi yang akan disampaikan kepada publik atau media harus akurat, mudah, dan cepat supaya nantinya kebijakan pemerintah sesuai dengan kebutuhan informasi untuk masyarakat luas dan agar mengetahui apa kebijakan pemerintah sudah sesuai dengan masyarakat kini. Seperti yang dikutip dari Baskin, Humaspemerintah 
mempunyai peran yang penting dalam menjaga suatu informasi berkembang di publik tentang masalah, isu-isu dan tindakan-tindakan di semua tingkatan pemerintahan. Selain itu, pihak petugas humas pemerintah jugaturut meminta persetujuan suatu masyarakat terhadap program pemerintah, serta membantu menjelaskan apa saja yang diinginkan warga dari pemerintah, lalu berusaha membuat pemerintahan yang responsif terhadap apa diinginkan masyarakat, dan berusaha untuk mempengaruhi dan memahami opini dari publik (Boztepe, 2016).

Dapat dikatakan humas adalah suatu kegiatan yang dilakukan untuk menanamkan pengertian/pemahaman agar memperoleh good will, kerja sama dankepercayaan yang suatu saat akan mendapat dukungan dari pihak lain. Tujuan Humas adalah untuk membina, memelihara, serta menciptakan sikap yang menyenangkan bagi lembaga atau organisasi di satu pihak dan dengan publik lain pihak, dengan komunikasi harmonis sekaligus adatimbal balik.

Dari kacamata media massa, publisitas adalah informasi disediakan oleh sumber luar yang digunakan oleh media karena informasi itu memiliki nilai berita. Jadi, publisitas merupakan informasi yang telah disediakan oleh narasumber luar yang dipakai media, sebab informasi tersebut memiliki nilai untuk dijadikan berita.

Kriyantono (2008:45) juga mendefinisikan keuntungan diperoleh dari publisitas, yaitu adanya publisitas mengandung kredibilitas tinggi di mata khalayak media, khalayak ini dianggap lebih mempercayai informasi publisitas yang dikemas dalam sajian berita.Di mata khalayak, informasi atau berita adalah fakta yang tidak direkayasa, penulis berita (yang menceritakan) bukan perusahaan, tetapi media.Media di mata khalayak dianggap sebagai sumber informasi yang dapat dipercaya termasuk informasi atau berita yang disajikan tidak mengesankan berisi pesan-pesan menjual. Jadi publisitas akan lebih dipercaya pihak masyarakat dibandingkan dengan iklan. Fakta dimaksud dapat kita lihat respon yang ada dari masyarakat di saat surat kabar atau televisi yang mempublisitaskan sebuah informasi yang mereka kemas ke dalam bentuk berita.pembaca akan menganggap informasi tersebut sebagi berita yang akurat dan dapat dipercaya. Begitu juga yang dilakukan oleh Humas Pemerintah Kabupaten Jembrana, khususnya Bagian Humas dan Protokol Sekretariat Daerah Kabupaten Jembrana memposisikan diri sebagai gerbang suatu informasi bagi publik dan media. Dari itu, pihak pemerintah melalui Bagian Humas danProtokol Setda Pemerintah Kabupaten Jembrana melibatkan humasnya dalam penyebaran informasi ke media massa.

Komunikasi berfungsi sebagai penghubung yang menjembatani citacita dan aspirasi antara masyarakat dengan pemerintah secara timbal balik. Aspirasi dan cita-cita masyarakat akan tertampung sehingga mereka merasa ikut serta, dan dengan sendirinya akan memberikan dukungan serta dorongan dari masyarakat.

Hadirnya Humas dan Protokol pemerintah sendiri mempunyai fungsi untuk bisa meningkatkan citra positif, menjadi wadah bersama untuk saling 
berinteraksi, meningkatkan reputasi, menjalin hubungan yang baik antar stakeholder, membangun kepercayaan kepada instansi dan masyarakat.Humas pemerintah dapat dikatakan sebagai wakil dari pemerintah yang memberikan informasi dari pemerintah kepada masyarakat luas, humas juga menyampaikan informasi baru kepada pemerintah dari pendapat masyarakat, baik itu kritik ataupun saran.Menurut Gleen Broom dan David Dozier (dalam Karlina, 2014) tugas Humas adalah menjembatani bagi organisasi dengan publiknya dalam mencari solusi yang akanmewadahi kepentingan di kedua belah pihak.

\section{Metode Penelitian}

Penelitian dilakukan di Kantor Humas dan Protokol Sekretariat Daerah, Kab.Jembrana.Penelitianini menggunakanpendekatan penelitian survey dengan format penelitian kuantitatif. Populasi dalam penelitian ini adalah pegawai pada Kantor Humas dan Protokol Sekretariat Daerah, Kab.Jembrana, berjumlah 35 orang. Teknik analisis data digunakan adalah regresi linier berganda.

\section{B. Landasan Teori \\ Pengertian Efektivitas}

Sondang P. Siagian, (2011:151) mengatakan bahwa: "Efektivitas kerja adalah penyelenggaraan penyelesaian pekerjaan tepat pada waktu yang telah ditentukan. Di mana pelaksanaan suatu tugas dinilai baik ataupun tidak,sangat tergantung bilamana diselesaikan dan tidak terutama menjawab pertanyaan bagaimana cara melaksanakan beserta berapa biaya dikeluarkan untuk itu”.
Tugas protokoler; menentukan keberhasilan atas kegiatan yang akandilaksanakan oleh organisasi ataupun institusi. Disamping itu, protokol juga merupakan bagian yang melekat dari aktivitas pemerintahan dan mewarnai budaya kerja, terutama bagi petugas protokol yang sangat dekat perannya di dalam mendukung kelancaran tugasyang dilakukan kepemimpinan, baik di tingkat lokal maupun nasional.

Diperlukan adanya keberadaan protokol di dalam lembaga pemerintah/ perusahaan adalah karena protokol ikut menentukan tercipta suasana yang bisa berpengaruh atas keberhasilan acara dibuat oleh perusahaan tersebut. Selain itu, dapat menciptakan tata pergaulan yang mendekatkan satu sama lain dan bisa diterima semua pihak, terciptanya upacara yang khidmat, megah, dan agung, serta terciptanya ketertiban dan rasa aman dalam menjalankan tugas (Dalam Undang-Undang RI Nomor 9 Tahun 2010 BAB 1 Pasal 1 tentang Keprotokolan.p.131).Ruang Lingkup Tugas, dan Fungsi Protokol

1. Luasnya ruang lingkup tugas protokol yang menyangkut tata cara penghormatan, tata tempat, dan tata upacara tercermin di dalam banyaknya macam acara yang harus dilaksanakan. Dalam Undang-Undang RI Nomor 9 Tahun 2010 BAB 1 Pasal 1 tentang Keprotokolan.p.131). Ruang Lingkup Tugas, dan Fungsi Protokol, yaitu seperti:

a) Penerimaan tamu/audensi (dalam dan luar negeri)

b) Kunjungan tamu (dalam dan luar negeri) 
c) Perjalanan ke daerah/luar negeri

d) Pengaturan rapat/sidang

e) Penyelenggaraan resepsi/jamuan makan

f) Penyelenggaraan upacaraupacara :

g) Hari besar nasional

h) Hari besar keagamaan

i) Peresmian proyek

j) HUT organisasi

k) Upacara bendera

1) Pelantikan dan serah terima jabatan

m) Crendetials

n) Penandatanganan Kerjasama Internasional

o) Peresmian pembukaan / penutupan seminar /lokakarya, dll.

\section{Pengertian citra}

Citra adalahtujuanutama sekaligusmerupakanreputasidan prestasi yang hendak dicapaidunia kehumasan atau public relations. Pengertiancitraitu

abstrakdantidak dapatdiukur

secaramatematis,

t e tapiwujudnyamampu

dirasakandarihasilpenilaian baik atau buruk dari khalayak itu sendiri (Ruslan,2003:68).
MenurutBillCantondalamSukatend el(1990)yang dikutipdari bukunya SoemiratdanArdianto(2002), mengatak anbahwacitra adalah "image : the impression, the feeling,the conception, whichthe public has of a company, a concioussly created created impression of an object,personororganization”.Yang artinya,citramerupakan suatu kesan, perasaan, terkaitgambaran diri publik terhadap perusahaan, kesan publik yang muncul sengaja diciptakandarisuatuobyek,orangatauorg anisasi.Jadi,citra

adalahcarabagaimanapihaklainmemand ang sebuah lembaga, organisasi, seseorang, suatu komite atau suatu aktivitas.

\section{Pembahasan}

Untuk mengetahui efektivitas pelaksanaan tugas dan fungsi di bagian humas dan protokol dalam menjaga citra kepala daerah, dapat dilihat dari item-item yang digunakan dalam indikator-indikator pada angket yang telah disebarkan kepada responden (karyawan bagian Biro, Kabag, Kasubag dan Staf yang terkait dengan pelaksanaan humas dan keprotokolan) dengan penyajian hasil dalam bentuk tabel di bawah ini. 
Rekapitulasi Skor Efektivitas Pelaksanaan Tupoksi dalam Menjaga Citra

Kepala Daerah

\begin{tabular}{|c|c|c|c|c|c|c|c|c|c|c|c|c|c|}
\hline \multirow[t]{2}{*}{ Keterangan } & \multirow{2}{*}{$\begin{array}{c}\text { No } \\
\text { Perta } \\
\text { nyaan }\end{array}$} & \multicolumn{4}{|c|}{$\begin{array}{c}\text { Frekuensi } \\
\text { Jawaban }\end{array}$} & \multirow{2}{*}{$\begin{array}{l}\text { Total } \\
\text { Respon } \\
\text { Den }\end{array}$} & \multicolumn{4}{|c|}{ Skor Jawaban } & \multirow{2}{*}{$\begin{array}{l}\text { Total } \\
\text { Skor }\end{array}$} & \multirow{2}{*}{$\begin{array}{l}\text { Rata- } \\
\text { rata }\end{array}$} & \multirow[t]{2}{*}{ Kategori } \\
\hline & & TS & CS & $\mathrm{S}$ & SS & & 1 & 2 & 3 & 4 & & & \\
\hline \multirow{6}{*}{$\begin{array}{l}\text { Efektivitas } \\
\text { Pelaksanaan } \\
\text { Tupoksi }\end{array}$} & 1 & 0 & 3 & 22 & 10 & \multirow{11}{*}{35} & 0 & 6 & 66 & 40 & 112 & 3,20 & Efektif \\
\hline & 2 & 0 & 1 & 19 & 15 & & 0 & 2 & 57 & 60 & 119 & 3,40 & Efektif \\
\hline & 3 & 1 & 2 & 23 & 9 & & 1 & 4 & 69 & 36 & 110 & 3,14 & Efektif \\
\hline & 4 & 2 & 3 & 22 & 8 & & 2 & 6 & 66 & 32 & 106 & 3,03 & Efektif \\
\hline & 5 & 1 & 9 & 21 & 4 & & 1 & 18 & 63 & 16 & 98 & 2,80 & $\begin{array}{l}\text { cukup } \\
\text { efektif }\end{array}$ \\
\hline & 6 & 0 & 5 & 21 & 9 & & 0 & 10 & 63 & 36 & 109 & 3,11 & $\begin{array}{l}\text { cukup } \\
\text { efektif }\end{array}$ \\
\hline \multirow{5}{*}{$\begin{array}{l}\text { Citra } \\
\text { Kepala } \\
\text { Daerah }\end{array}$} & 0 & 5 & 21 & 9 & 0 & & 0 & 10 & 63 & 36 & 109 & 3,11 & Efektif \\
\hline & 0 & 4 & 25 & 6 & 0 & & 0 & 8 & 75 & 24 & 107 & 3,06 & Efektif \\
\hline & 0 & 8 & 21 & 6 & 0 & & 0 & 16 & 63 & 24 & 103 & 2,94 & Efektif \\
\hline & 0 & 8 & 22 & 5 & 0 & & 0 & 16 & 66 & 20 & 102 & 2,91 & Efektif \\
\hline & 0 & 5 & 21 & 9 & 0 & & 0 & 10 & 63 & 36 & 109 & 3,11 & Efektif \\
\hline \multicolumn{11}{|l|}{ Total Skor } & 1184 & & \\
\hline \multicolumn{11}{|c|}{ Rata-rata Skor } & & 3.07 & Efektif \\
\hline
\end{tabular}

Sumber: Lampiran 3, data diolah 
Dari tabel 13 dapat dilihat bahwa rata-rata skor variable terkait efektivitas pelaksanaan tupoksi dalam menjaga citra kepala daerah adalah 3,07 yang mana tergolong di dalam kategori efektif, yang berarti bahwa pelaksanaan tugas dan fungsi bagian humas dan protokol dalam menjaga citra kepala daerah Pada Bagian Humas dan Protokol Sekretariat daerah Kabupaten Jembrana) telah dilaksanakan dengan efektif.

1. Efektivitas pelaksanaan tupoksi

a. Penerimaan tamu/audensi (dalam dan luar negeri) terlaksana sesuai dengan standar yang ditentukan. Hal tersebut bisa dibuktikan dari pernyataan responden, bahwa penerimaan tamu/audensi (dalam dan luar negeri) yang dilakukan oleh Bagian Humas dan Protokol Setda Kabupaten Jembrana sudah terlaksana sesuai dengan standar yang ditentukan.

b. Kunjungan tamu (dalam dan luar negeri) dilaksanakan sesuai atas pedoman yang berlaku. Hal ini dapat dibuktikan dari pernyataan responden, bahwa kunjungan tamu dalam dan luar negeri telah dilaksanakan oleh Bagian Humas dan Protokol SetdaKabupaten Jembrana sesuai pedoman yang berlaku

c. Perjalanan ke daerah/luar negeri jugadilaksanakansesuai dengan pedoman yang ditentukan. Hal ini dibuktikan melalui pernyataan responden, bahwa perjalanan ke daerah/luar negeri dilaksanakan oleh Bagian Humas dan
Dari hasil analisis data yang telah dilakukan, bahwa pelaksanaan tugas dan fungsi Bagian Humas dan Protokol di dalam Menjaga Citra Kepala Daerah Sekretariat daerah Kabupaten Jembrana, jika dilihat dari sejumlah data pernyataan responden melalui penyebaran kuisioner pada responden, indikator-indikator yang digunakan ke dalam penelitian ini, yaitu sebagai berikut:

ProtokolSetdaJembrana, sesuai pedoman yang ditentukan.

d. Pengaturan terkait rapat/sidang dilaksanakan baik. Hal ini dapat dibuktikan dari pernyataan pihak responden, bahwa pengaturan rapat/sidang pada Bagian Humas dan Protokol Setda Kabupaten Jembrana sudah dilaksanakandengan baik.

e. Penyelenggaraan resepsi/jamuan makan telah dilaksanakan dengan baik. Hal ini dibuktikan melaluipernyataan responden, bahwapenyelenggaraan resepsi/jamuan makan pada Bagian Humas dan Protokol Setda Kabupaten Jembr ana sudah baik dilakukan.

f. Penyelenggaraan terkait upacaraupacara kenegaranaan juga sudah sesuai dengan aturan ditetapkan. Hal ini dapat dibuktikan dari pernyataan responden, bahwa upacarakenegaraanyang digelar sudah sesuai dengan aturan yang ditetapkan pada Bagian Humas dan Protokol Setda Kabupaten 
Jembrana, sudah dilaksanakan dengan baik

2. Citra Kepala Daerah

a. Personality kepala daerah meningkat dengan terlaksananya kegiatan humas dan protokol dengan baik. Hal ini dibuktikan daripernyataan pihak responden, bahwa personality kepala daerah meningkat dengan terlaksananya kegiatan dari humas dan protokol dengan baik

b. Reputation Kabupaten Jembrana meningkat melalui terlaksananya kegiatan humas dan protokol dengan baik. Hal ini dapat dibuktikan dari pernyataan responden, bahwa Reputation Kabupaten Jembrana meningkat terlaksananya kegiatan humas dan protokol dengan baik.

c. Value atau nilai dari Kabupaten Jembrana bisa meningkat dengan terlaksananya kegiatan humas dan protokol dengan baik. Hal ini dapat dibuktikan dari pernyataan responden, bahwa value ataupun nilai Kab. Jembrana meningkat dengan terlaksananya kegiatan humas dan protokol dengan baik.

d. Identity atau jadi diri bisa dilihat dengan terlaksananya kegiatan humas dan protokol dengan baik. Hal ini dapat dibuktikan dari pernyataan responden, bahwa Identity atau jadi diri bisa dilihat dengan terlaksananya kegiatan humas dan protokol dengan baik

\section{Penutup}

1. Simpulan

Efektivitas pelaksanaan tugas dan fungsi dari Bagian Humas dan Protokol dapat menjaga citra kepala daerah pada Sekda Kab. Jembrana, hal ini dapat dilihat dari:

a. Penerimaan tamu/audensi (dalam dan luar negeri) terlaksana sesuai dengan standar yang ditentukan.

b. Kunjungan tamu (dalam dan luar negeri) dilaksanakan sesuai dengan pedoman yang berlaku.

c. Perjalanan ke daerah/luar negeri dilaksanakan sesuai dengan pedoman yang ditentukan.

d. Pengaturan rapat/sidang dilaksanakan dengan baik.

e. Penyelenggaraan resepsi/jamuan makan sudah dilaksanakan dengan baik.

f. Penyelenggaraan upacaraupacara kenegaraan sudah sesuai dengan aturan yang ditetapkan.

g. Personalitykepala daerah meningkat dengan terlaksananya kegiatan humas dan protokol dengan baik.

h. Reputation Kabupaten Jembrana meningkat denganterlaksananya kegiatan humas dan protokol dengan baik.

i. Value atau nilai Kabupaten Jembrana meningkat dengan terlaksananya kegiatan humas dan protokol dengan baik. 
j. Identity atau jadi diri bisa dlihat dengan terlaksananya kegiatan humas dan protokol dengan baik.

2. Saran

Mengingat bagian dari Humas dan Protokol mempunyai peran penting untuk meningkatkan citra dari kepala daerah, maka itu perlu ditingkatkan kegiatan yang dapatmendukung efektivitas kegiatan protokoler, di mana dengan melakukan persiapan menerima tamu luar ataupun dalam negeri. Selain itu menyiapkan kunjungan-kunjungan kedinasan agar bisa berjalan dengan baik, mengatur acara rapat dan sidang agar dapat berjalan sesuai dengan standar ditetapkan dan melakukan persiapan lebih baik dalam proses penyelengaraan upacara kenegaraan, sehingga dapat meningkatkan citra kepala daerah di masyarakat dalam atau luar negeri.

\section{DAFTAR PUSTAKA}

Nasution, Zulkarnaen. (2006). Manajemen

Humas di Lembaga Pendidikan.

Malang: UPT. Penerbitan

Universitas Muhammadiyah

Malang

Kriyantono, Rachmat. 2008. Teknik Praktis

Riset Komunikasi. Jakarta :

Kencana.

Broom, Glenn. M., Dozier, David. M. 2000.

Using Research in Public Relations:

Application to Program

Management. New Jersey: Prentice

Hall

Sondang P. Siagian. 2011. Manajemen

Sumber Daya Manusia, Jakarta: PT.

Bumi.
Murchadarsyah Sinungan, 2002 "Dasar

Teknik manajemen Kredit";

Jakarta: Aksara.

Kartono, Kartini, 2011 Pemimpin dan Kepemimpinan. Jakarta: PT Raja Grafindo. Persada

Effendy, Onong Uchjana. 2008. Dinamika Komunikasi. Bandung: PT.

Remaja. Rosdakarya.

Suhandang, Kustadi. 2004. Public Relations Perusahaan: Kajian, Program, dan Implementasi. Bandung: Nuansa

Moore, H, Frazier. 2004. Humas Membangun Citra Dengan Komunikasi. Bandung: Remaja Rosda Karya.

Ruslan, Rosady. 2003. Metode Penelitian PR dan Komunikasi. Jakarata : PT. Raja. Grafindo Persada.

SoemiratdanArdianto.2002. Elvinaro Ardianto, Public Relation Praktis, Remaja Rosdakarya, Bandung, 2003, hlm:134.

Sugiyono, 2009, Metode Penelitian Kuantitatif, Kualitatif dan R\&D, Bandung: Alfabeta.

http://.panca.wordpress.com/2006/07/17/seja rah-kata-protokol

Undang-Undang Dasar Negara Republik Indonesia tahun 1945

Undang-Undang RI Nomor 9 Tahun 2010 tentang Keprotokolan 